\title{
IMPLEMENTASI KEBIJAKAN PEMERINTAH DESA TENTANG PEMBENTUKAN BADAN USAHA MILIK DESA DI DESA TANJUNGSARI KECAMATAN SUKALUYU KABUPATEN CIANJUR
}

\author{
Annisa Dwi Lestari' ${ }^{1}$, Dadan Kurnia², Agustina Setiawan ${ }^{3}$ \\ 1,2,3 Program Studi Ilmu Pemerintahan, Fakultas Ilmu Sosial dan Ilmu Politik, \\ Universitas Jenderal Achmad Yani, Indonesia
}

\begin{abstract}
Abstrak
Penelitian ini membahas terkait dengan Implementasi Kebijakan Pemerintah Desa Tentang Pembentukan Badan Usaha Milik Desa Di Desa Tanjungsari Kecamatan Sukaluyu Kabupaten Cianjur. Tujuan penelitian ini adalah untuk mendeskripsikan dan menganalisis Implementasi Kebijakan Pemerintah Desa Tentang Pembentukan Badan Usaha Milik Desa, Di Desa. Tanjungsari Kecamatan Sukaluyu Kabupaten Cianjur. Metode penelitian yang digunakan dalam penelitian ini yaitu menggunakan metode deskriptif kualitatif yakni untuk memberikan gambaran secara jelas mengenai masalah yang diteliti. Hasil penelitian menunjukkan bahwa Implementasi Kebijakan Pemerintah Desa Tentang Badan Usaha Milik Desa Di Desa Tanjungsari Kecamatan Sukaluyu Kabupaten Cianjur dapat dikatakan belum optimal. Hal tersebut dikarenakan antara lain (1) tujuan kebijakan tersebut bahwa BUMDes Desa Tanjungsari belum mampu memberdayakan seluruh masyarakat desa, (2) Pengurus BUMDes yang ada pada saat ini kurang dari segi kuantitas dan kualitas lalu cenderung sibuk dengan pekerjaannya masing-masing sehingga dalam mengimplementasikan kebijakan Pemerintah Desa tentang pembentukan badan usaha milik desa ini tidak diikuti dengan pengembangan jenis usaha yang baik, (3) Sumberdaya finansial yang tidak bisa mengembangkan seluruh jenis usaha, (4) Karakteristik dari agen pelaksana BUMdes berbeda-beda, (5) adanya sikap ketidaktegasan dan ketidakpatuhan dari para pelaksana kebijakan (6) kurangnya komunikasi antar Organisasi dan Aktivitas Pelaksana (7) lingkungan eksternal yang terdiri dari lingkungan politik, sosial dan ekonomi di desa tanjungsari berjalan dengan kondusif.
\end{abstract}

Kata Kunci: Implementasi Kebijakan, BUMDes 


\begin{abstract}
The title of this research is "Implementasi Kebijakan Pemerintah Desa Tentang Pembentukan Badan Usaha Milik Desa Di Desa Tanjungsari Kecamatan Sukaluyu Kabupaten Cianjur". This research uses descriptive method with qualitative approach that is to give a description about the problem in this research. With 7 informants, there are: The Headman of Tanjungsari Village, The Director of BUMDes, The Head Financial Unit of BUMDes, The Head of Service Section of Tanjungsari Village, The Head of Village Economic Institute DPMD Kab. Cianjur, The Head of Karang Taruna, and The Head of RT $002 R W 001$ as Tanjungsari Village community. The results represented that the Implementation of Village Government Policy About Badan Usaha Milik Desa in Tanjungsari Village Sukaluyu Cianjur has not been optimally. This was because (1) the policy objectives that BUMDes Tanjungsari Village has not been able to empower the entire village community, (2) the existing BUMDes lack in terms of quantity and quality of human resource then executives tend to stuck in with their respective jobs so that in implementing the policy of the Village Government about Badan Usaha Milik Desa was not followed by the development of a good business type. (3) Financial resources that cannot be develop all the types of business, (4) Characteristics of implementing agencies BUMdes different, (5) the existence of non-compliance attitude of the policy implementers (6) lack of communication between Organization and Activity Executor, (7) the external environment consisting of the political, social and economic environment in the tanjungsari village runs conducive.
\end{abstract}

Keywords : Policy Implementation, BUMDes

\title{
PENDAHULUAN
}

Dalam rangka untuk meningkatkan perekonomian dan kesejahteraan masyarakat desa, Pemerintah melalui Undang-Undang Nomor 6 tahun 2014 Tentang Desa yang ditindaklanjuti dengan Peraturan Pemerintah Nomor 43 tahun 2014 Tentang Peraturan Pelaksanaan Undang-undang Nomor 6 Tahun 2014 Tentang Desa dan Peraturan Menteri Desa Nomor 4 tahun 2015 Tentang Pendirian, Pengurusan, Pengelolaan dan Pembubaran Badan Usaha Milik Desa, menyatakan bahwa BUMDes adalah "lembaga usaha desa yang dikelola oleh mayarakat dan pemerintahan desa dalam upaya memperkuat perekonomian desa dan dibentuk berdasarakan kebutuhan dan potensi desa". 
Keberadaan BUMDes harus mampu menyerap tenaga kerja produktif dan potensial yang ada di desa. BUMDes juga dapat mengadakan pelatihan dan pembinaan yang bertujuan memberikan pembekalan keterampilan dan pengetahuan kepada penduduk desa. Kegiatan ini selain bermanfaat bagi pengembangan BUMDes juga menjadi upaya peningkatan kualitas sumber daya masyarakat desa yang pada umumnya masih terbelakang. Daya dukung sumber daya manusia pada pengembangan usaha BUMDes menjadi tolak ukur keberhasilan BUMDes itu sediri, sebab keberadaaan BUMDes dan keberhasilannya diukur dari seberapa perubahan yang mampu dihadirkan dalam kegiatan pengelolaan ekonomi di desa.

Kabupaten Cianjur sebagai perwujudan dari otonomi daerah memiliki banyak wilayah pedesaan dan mayoritas pemerintah desa didalamnya tentu sangat berperan dalam upaya peningkatan keberhasilan program - program yang dijalankan di desa seperti BUMDes tersebut. Hal ini dibuktikan dengan dibuatnya Peraturan Daerah (Perda) tentang BUMDes di Kabupaten Cianjur yaitu Peraturan Daerah Kabupaten Cianjur Nomor 3 tahun 2012 tentang Pedoman tata cara Pembentukan dan Pengelolaan Badan Usaha Milik Desa yang ditindak lanjuti dengan Peraturan Daerah Kabupaten Cianjur Nomor 4 tahun 2015 Tentang Desa. Dengan demikian, Perda tersebut dapat menjadi dasar hukum dalam menyelenggarakan dan melaksanakan program BUMDes walaupun nantinya akan mengacu kepada Peraturan Desa sesuai dengan desanya masing - masing.

Salah satu desa yang mendirikan BUMDes yaitu Desa Tanjungsari yang memiliki Peraturan Desa yang mengatur tentang BUMDes yaitu, Nomor 03 Tahun 2017 tentang Pembentukan Badan Usaha Milik Desa. Dalam Peraturan Desa ini dijelaskan bahwa "Pembentukan BUMDes adalah untuk mewadahi potensi usaha perekonomian masyarakat yang ada di Desa Tanjungsari”.

Desa Tanjungsari adalah salah satu desa yang berada di wilayah Kecamatan Sukaluyu Kabupaten Cianjur yang memiliki potensi sumber daya alam yang melimpah seperti pertanian, dilihat dari mayoritas penduduk desa sebagai petani, sehingga jika dikelola dengan baik Desa Tanjungsari bisa menjadi salah satu desa mandiri di Kabupaten Cianjur, yaitu desa yang bisa memenuhi kebutuhannya sendiri dan tidak semata-mata tergantung kepada 
bantuan pemerintah namun untuk mewujudkan hal itu sulit terjadi bahkan jumlah Keluarga miskin masih tinggi yaitu mencapai 897 keluarga.

Belum berjalan dengan optimalnya Implementasi Kebijakan tentang Pembentukan Badan Usaha Milik Desa di Desa Tanjungsari tersebut peneliti melihat bahwa pelaksana operasional BUMDes belum berkompenten hal tersebut dibuktikan dengan latar belakang pekerjaan yang kurang mendukung dalam mengoperasionalkan BUMDes di Desa Tanjungsari untuk mengembangkan jenis usaha yang ditetapkan dalam Perdes tentang BUMDes tersebut (dalam Departemen Pendidikan Nasional (PKDSP), 2007: 25) menyebutkan bahwa "BUMDes harus dikelola secara profesional dan mandiri sehingga diperlukan orang-orang yang memiliki kompetensi untuk mengelolanya, contohnya bagi pemegang jabatan manajer setidak-tidaknya memiliki pengalaman kerja di lembaga yang bertujuan mencari keuntungan".

Menurut Carl Friedrich (dalam Winarno, 2007) kebijakan adalah sebagai suatu arah tindakan yang diusulkan oleh seseorang, kelompok, atau pemerintah dalam suatu lingkungan tertentu, yang memberikan hambatanhambatan dan peluang-peluang terhadap kebijakan yang diusulkan untuk menggunakan dan mengatasi dalam rangka mencapai suatu tujuan, atau merealisasikan suatu, sasaran atau maksud tertentu. Sedangkan menurut Anderson (dalam Winarno, 2007: 18) menyatakan bahwa: "Kebijakan merupakan arah tindakan yang mempunyai maksud yang ditetapkan oleh seorang aktor atau sejumlah aktor dalam mengatasi suatu masalah atau suatu persoalan".

Sementara itu menurut Donald Van Metter dan Carl Van Horn (dalam Agustino, 2016) menyatakan bahwa ada beberapa variabel yang memengaruhi kinerja implementasi kebijakan public, yaitu ukuran dan tujuan kebijakan, sumber daya, karaktersitik agen pelaksana, sikap atau kecenderungan para pelaksana, komunikasi antar organisasi dan aktivitas pelaksana, dan lingkungan ekonomi, sosial, dan politik. implementasi kebijakan proses menerjemahkan peraturan ke dalam bentuk tindakan, sesuatu yang penting untuk dilakukan untuk melihat tujuannya sudah tercapai atau tidak, dan melalui prosedur inilah suatu masalah publik dapat diselesaikan atau tidak. Implementasi merupakan suatu proses yang dinamis, di mana pelaksana 
kebijakan melakukan suatu aktivitas atau kegiatan sehingga pada akhirnya akan mendapatkan suatu hasil yang sesuai dengan tujuan atau sasaran kebijakan itu sendiri.

Kondisi BUMDes di Desa Tanjungsari yang belum mampu memenuhi harapan sesuai dengan maksud dan tujuan pendiriannya, karena terdapat beberapa Masalah yang masih di rasakan sebagai faktor penghambat bagi pertumbuhannya. Dalam implementasi kebijakan tentang pembentukan Badan Usaha Milik Desa di Desa Tanjungsari guna mencapai tujuannya, terdapat hal-hal, berupa fenomena- fenomena negatif yang muncul di Desa Tanjungsari tersebut dan itulah yang masih dirasakan sebagai masalah sehingga tujuan didirikannya BUMDes tersebut, belum mampu mewujudkan tujuan yang dikehendakinya. Adapun gejala-gejala permasalahan yang ditemui di lapangan bahwa masyarakat belum memperoleh manfaat secara konkrit dalam peningkatan kesejahteraan masyarakat dengan adanya BUMDes termaksud karena agen pelaksana yaitu Sumber daya manusia yang terbatas dan kurang berkompeten dalam mengoperasionalkan BUMDes sehingga masyarakat belum mendapat manfaat dari keberadaan BUMDes tersebut.

Kurangnya Koordinasi dengan Pemerintah Daerah atau dinas yang terkait yaitu Dinas Pemberdayaan Masyarakat dan Desa dilihat dari kurangnya pembinaan dan bimbingan juga dukungan berupa bantuan dana financial maupun non financial. hal ini disebabkan karena Pemerintah daerah Kabupaten Cianjur belum mengadakan program khusus untuk pengembangan BUMDes ke Pemerintahan Desa, seperti bimbingan teknis mengenai BUMDes, pembinaan terhadap pengurus BUMDes, dan pelatihan pengelolaan keuangan BUMDes. Melalui pembinaan dan bimbingan tersebut diharapkan agar BUMDes di Desa Tanjungsari ini dapat berkembang.

Dalam implementasi Kebijakan BUMDes di Desa Tanjungsari guna mencapai tujuannya, terdapat gejala-gejala permasalahan yang muncul di lapangan yang ditemui oleh peneliti, dan hal itu yang masih dirasakan sebagai masalah sehingga tujuan didirikannya BUMDes tersebut, belum mampu mencapai tujuan yang dikehendaki salah satunya yaitu belum mampu menaikan pendapatan asli desa. 
Dari gejala-gejala permasalahan yang ditemui oleh peneliti maka peneliti tertarik untuk melakukan penelitian lebih lanjut untuk memilih Badan Usaha Milik Desa di Desa Tanjungsari, peneliti lebih tertarik dan menetapkan proses penelitian serta menyusunnya dalam bentuk skripsi dengan judul: Implementasi Kebijakan Pemerintah Desa Tentang Pembentukan Badan Usaha Milik Desa, Di Desa Tanjungsari Kecamatan Sukaluyu Kabupaten Cianjur.

\section{METODE PENELITIAN}

Dalam Penelitian ini digunakan metode penelitian deskriptif, guna mengetahui atau menggambarkan kenyataan dari kejadian yang diteliti atau yang dilakukan peneliti terhadap variabel mandiri atau tunggal, yaitu tanpa membuat perbandingan atau menghubungkan dengan variabel lain. Sehingga memudahkan peneliti untuk mendapatkan data objektif mengenai Implementasi Kebijakan Pemerintah Desa Tentang Pembentukan Badan Usaha Milik Desa (BUMDes) Di Desa Tanjungsari Kecamatan Sukaluyu Kabupaten Cianjur. Peneliti menggunakan pendekatan penelitiaan kualitatif dengan metode deskriptif. Menurut Sugiyono (2014: 9) metode penelitian kualitatif yaitu metode Penelitian Kualitatif adalah metode penelitian yang berlandaskan pada filsafat postpositivisme, digunakan untuk meneliti pada kondisi obyek yang alamiah, (sebagai lawannya adalah eksperimen) dimana peneliti adalah sebagai insrumen kunci, Teknik pengumpulan data dilakukan secara triangulasi (gabungan), analisis data bersifat induktif/kualitatif, dan hasil penelitian kualitatif lebih menekankan makna dari pada generalisasi

Penelitian ini menggunakan 2 (dua) data yaitu data primer dan data sekunder. Penelitian ini dilakukan di Desa Tanjungsari Kecamatan Sukaluyu Kabupaten Cianjur. Dalam penelitian ini unit analisisnya adalah Badan Usaha Milik Desa Tanjungsari Mekar Desa Tanjungsari Kecamatan Sukaluyu Kabupaten Cianjur, maka dari itu ditentukan sejumlah informan sebagai sumber informasi yang meliputi: Kepala Desa Tanjungsari, Direktur BUMDes, Ketua Unit Usaha Keuangan BUMDes, Kasi Pelayanan Desa Tanjungsari, Seksi Bina Lembaga Ekonomi Desa DPMD Kab. Cianjur, Pengurus Karang taruna, Ketua RT 002 RW 001. Teknik pengumpulan data dalam penelitian ini 
dilakukan dengan observasi, wawancara, dan dokumentasi.

Dalam observasi ini, peneliti terlibat dengan kegiatan sehari-hari orang yang sedang diamati atau di gunakan sebagai sumber data penelitian. Menurut Nasution (dalam Sugiyono, 2013: 64) menyatakan bahwa "Observasi adalah dasar semua ilmu pengetahuan". Untuk melengkapi data penelitian, maka peneliti melakukan observasi terhadap lokasi penelitian, yaitu di Desa Tanjungsari Kecamatan Sukaluyu Kabupaten Cianjur Rencana Pengujian Data. Sementara itu, wawancara dilakuan utnuk mengetahui hal-hal ya g lebih mendalam tentang partisipasi dalam menginterpretasikan situasi dan fekomena yang terjadi, dimana hal ini tidak dapat ditemukan melalui observasi (Sugiyono, 2013). Teknik analisis data dalam penelitian ini yaitu data reduction, data display, dan conclusion drawing/ verification. Sedangkan dokumentasi atau studi kepustakaan dilakukan dengan mengumpulkan dan Menyusun data atau sumber pendukung yang diperoleh dari buku literature, media internet, dokumen-dokumen, perundang-undangan yang berkaitan denagn materi penelitian.

\section{HASIL DAN PEMBAHASAN}

\section{Ukuran dan Tujuan Kebijakan}

Kebijakan BUMDes sendiri memang sudah dianjurkan pada tahun 2007 oleh kementrian dalam negeri saat itu yang tertuang dalam Permendagri No.37 Tahun 2007 tentang Pedoman Pengelolaan Keuangan Desa dan di tahun yang sama 2007 juga di Kabupaten Cianjur sudah ada BUMDes yang terbentuk yaitu Desa Kademangan Kecamatan Mande. Pada saat itu Permendagri No.37 Tahun 2007 masih dalam tahap penyesuaian sehingga diturunkannya Permendagri No. 39 tahun 2010 yang memuat khusus bagaimana mekanisme BUMDes itu dibuat agar lebih banyak lagi desa yang membentuk BUMDes. Untuk mendorong desa dalam membentuk BUMDes masing masing berawal dari inisiatf desa dan didorong oleh program-program pemerintah daerah, Di Kabupaten Cianjur sendiri pada tahun 2010 hingga 2014 BUMDes mengalami permasalahan berkaitan dengan permodalan sampai pada tahun 2014 dikeluarkanlah 
Peraturan Pemerintah no.43 tahun 2014 disitu menyatakan bahwa modal BUMDes dapat bersumber dari APB Desa.

Kabupaten Cianjur membuat Perda tentang BUMDes sendiri baru dibuat pada tahun 2012 yaitu Peraturan Daerah Kabupaten Cianjur No. 03 Tahun 2012 Tentang Pedoman Tata Cara Pembentukan dan Pengelolaan Badan Usaha Milik Desa, sedangkan dalam Permendagri No. 39 Tahun 2010 sendiri menyebutkan dalam pasal 3 ayat (2) yang berbunyi "Peraturan Daerah Kabupaten/Kota sebagaimana dimaksud pada ayat (1) ditetapkan paling lambat 1 tahun sejak Peraturan Mentri ini ditetapkan “. Jika Permendagri No.39 Tahun 2010 ditetapkan pada tahun 2010 maka tahun 2011 Pemerintah Daerah harus membuat Perda tersebut. Akan tetapi di Kabupaten Cianjur sendiri Perda yang mengatur tentang BUMDes dibuat pada tahun 2012. Desa-desa yang ada di Kabupaten Cianjur dalam membentuk BUMDes sebagian tidak mengacu pada Peraturan Daerah begitupun dengan Desa Tanjungsari dalam membuat regulasinya tidak mengacu pada Peraturan Daerah namun pada Permendesa No.4 Tahun 2015 Tentang Pendirian Pengurusan, pengelolaan dan pembubaran badan usaha milik desa.

Berdasarkan hasil wawancara dan observasi yang peneliti lakukan terkait Tujuan dan Ukuran kebijakan maka peneliti dapat menganalisis bahwa hanya sekitar 35\% saja desa yang memiliki BUMDes di Kabupaten Cianjur terbukti dari 354 desa hanya ada 123 Desa yang membentuk BUMDes.

Badan Usaha Milik Desa di Desa Tanjungsari berdiri pada tahun 2017, dengan dasar Peraturan Desa No. 3 Tahun 2017, Peraturan ini mengacu pada Permendesa No. 4 Tahun 2015 tentang Pendirian, Pengurusan, Pengelolaan, dan Pembubaran Badan Usaha Milik Desa. Selain itu dalam membentuk BUMDes juga Pemerintah Desa Tanjungsari berawal dari usulan Pemerintah Desa ke masyarakat lalu adakannya musyawarah desa. Namun Pemerintah Desa Tanjungsari sangat menyayangkan karena sampai saat ini payung hukum untuk BUMDes di Kabupaten Cianjur belum secara rinci membahas tentang BUMDes karna 
menunggu Peraturan Bupati yang sampai saat ini belum keluar peraturannya. Seperti sebelumnya peneliti jelaskan bahwa pertama kali Kabupaten Cianjur membuat regulasi tentang BUMDes pada Tahun 2012 yaitu Peraturan Daerah Kabupaten Cianjur No. 3 Tahun 2012 Tentang Pedoman Tata Cara Pembentukan Badan Usaha Milik Desa dan saat ini di tindaklanjuti pada Peraturan Daerah Kabupaten Cianjur No. 4 Tahun 2015 Tentang Desa.

\section{Sumber daya}

Salah satu keberhasilan suatu implementasi kebijakan adalah dipengaruhi ketersediaan sumber daya yang mencukupi, dalam hal ini manusia merupakan sumber daya yang paling utama. Kualitas sumber daya manusia dalam artian kualitas para pelaksana kebijakan akan sangat mempengaruhi terhadap keberhasilan suatu kebijakan. Diluar dari sumber daya manusia tersebut ada sumber-sumber daya yang lain yang dapat mempengaruhi terhadap keberhasilan suatu implementasi kebijakan seperti sumber daya finansial dimana sumber finansial juga sangat mempengaruhi terhadap keberhasilan suatu implementasi kebijakan, ketika sumber daya manusia yang kompeten dan kapabel telah tersedia sedangkan kucuran dana melalui anggaran tidak tersedia maka memang menjadi permasalahan untuk merealisasikan apa yang hendak dituju oleh tujuan kebijakan tersebut, karena itu sumber daya diminta dan dimaksud oleh van Metter dan van Horn adalah kedua bentuk sumberdaya tersebut, maka jika dilihat dari sumberdaya yang dimaksud tersebut dalam pelaksanaan kebijakan BUMDes di Desa Tanjungsari kedua bentuk sumberdaya tersebut sangat berpengaruh.

\section{a) Kualitas Sumber Daya Manusia}

Berdasarkan hasil wawancara dan observasi yang peneliti lakukan terkait Sumber Daya Manusia maka peneliti dapat menganalisis bahwa untuk mengurus BUMDes disesuaikan dengan kebutuhan dilapangan yaitu disesuaikan dengan rencana jenis usaha yang nantinya akan 
dilaksanakan, akan tetapi kenyataannya unit pelaksana dilapangan merasa kekurangan orang untuk membantu pekerjaan mereka dilapangan, karna proses pelaksanaan kebijakan BUMDes di Desa Tanjungsari ini yang paling berperan adalah Pemerintah Desa karna Pemerintah Desa berperan penting dalam memilih pelaksana operasional BUMDes.

Kondisi Sumber daya manusia dalam pelaksanaan BUMDes di Desa Tanjungsari ini adalah sumber daya manusia yang sifatnya relawan dan tidak ada gaji tetap, sehingga Pemerintah Desa ada kesulitan dalam memilih orang-orang untuk mengurus BUMDes karna sangat sedikit masyarakat yang berminat menjadi pengurus BUMDes karna dalam pelaksanaannya dibutuhkan orang yang benar- benar mau bekerja dan mencari orang-orang relawan pada saat ini memang sulit banyak beberapa dari masyarakat yang menjadi ukuran adalah dengan materi bukan mengukur untuk kemajuan desa, maka dari itu orang-orang yang tercantum dalam struktural adalah orang-orang yang bersosial namun sangat disayangkan mayoritas dari mereka dalam mengelola BUMDes terbentur dengan pekerjaan mereka masing-masing sehingga peneliti melihat bahwa dengan pekerjaan mereka diluar BUMDes mempengaruhi kinerja mereka dalam mengelola BUMDes terbukti dengan belum ada jenis usaha yang berjalan, adanya ketidak fokusan pengurus dalam mengelola BUMDes karna terbentur dengan pekerjaannya masingmasing membuat mereka tidak terlalu mementingkan Badan Usaha Milik Desa padahal dalam aturan tentang BUMDes itu sendiri bahwa pengurus BUMDes harus dapat mendahulukan kepentingan BUMDes diatas kepentingan lainnya.

Dilihat dari latar belakang Pendidikan pengurus BUMDes pada tabel 3, sebagai Sumber Daya Manusia pelaksana kebijakan BUMDes di Desa Tanjungsari ada beberapa yang berpendidikan rendah dengan tamatan SD dan SMP Dengan demikian Sumber Daya Manusia yang ada terutama pada latar belakang Pendidikan mempengaruhi kemampuan kinerja dalam pelaksanaan BUMDes, Pendidikan dapat menjadi salah satu ciri kualitas dari Sumber Daya Manusia, agar berjalan dengan 
efektif dan efisein dalam suatu pelaksanaan kebijakan tentang BUMDes karna tingkat Pendidikan sangat mempengaruhi kualitas kinerja BUMDes karna banyakan ketidak berhasilan suatu kebijakan adalah dipengaruhi oleh kualitas dari pelaksana kebijakan tersebut yang kurang baik, sehingga dengan demikian amatlah penting kualitas sumber daya manusia pada suatu implementasi kebijakan.

\section{b) Ketersediaan Sumber Daya Finansial}

Ketersediaan Sumber Daya Finansial dalam suatu implementasi kebijakan merupakan suatu hal yang tidak kalah pentingnya dari kualitas Sumber Daya Manusia, karna dalam mengimplementasikan suatu kebijakan diperlukan sumber dana yang cukup, baik untuk membiayai operasional pelaksana kebijakan ataupun membiayai operasional yang menjadi sasaran dari suatu kebijakan.

Untuk kebijakan tentang BUMDes di Desa Tanjungsari itu sendiri salah satu sumber dananya yaitu berasal dari Dana desa dan dapat didukung dari dana-dana yang lain karna berbicara terkait sumber daya finansial tidak akan lepas dari anggaran desa dimana desa akan menerima dana dari pemerintah pusat yang harus dikelola dengan baik oleh desa seperti yang dikatakan oleh Kasi Pelayanan Desa Tanjungsari menyatakan bahwa, modal untuk BUMDes saat ini hanya mengandalkan dari Dana Desa saja tentunya modal yang ada ini sangat terbatas sehingga belum bisa menjalankan semua jenis usaha yang direncanakan dana saat ini kami ambil 3.48\% dari dana desa Rp.916.093.000 yaitu sebesar Rp.35.000.000. Dengan dana yang jumlahnya sangat terbatas maka diperlukan solusi untuk mengatasinya agar dengan dana 35 juta tersebut dapat di maksimalkan terlebih dahulu, sesuai dengan pernyataan dari Kepala Desa Tanjungsari bahwa Dana yang ada sekarang memang belum dapat mengembangkan semua jenis usaha karna untuk saat ini hanya mengandalkan dari dana desa saja makadari itu kami mengambil prioritas mana yang akan dikembangkan dan kami memilih untuk mengembangkan jenis usaha perdagangan terlebih dahulu lalu setelah itu kami akan mengembangkan 
jenis usaha pertanian.

Selanjutnya peneliti mewawancarai Direktur dari BUMDes di Desa Tanjungsari beliau menyatakan bahwa, Dana BUMDes yang ada pada saat ini kalau berbicara cukup atau tidak saya rasa ini belum cukup namun kita berusaha untuk memaksimalkan terlebih dahulu modal yang ada karena berbicara anggaran sebesar apapun modalnya jika dikelola dengan tidak baik itu tidak akan merasa cukup menurut saya, maka dari itu BUMDes Desa tanjungsari berfokus pada usaha perdagangan terlebih dahulu nah selanjutnya nanti saya ingin mengembangkan permodalan masyarakat melalui simpan pinjam untuk modal masyarakat hal ini untuk mencegah banyaknya renterir yang ada di desa tanjungsari.

Berdasarkan hasil wawancara yang peneliti lakukan terkait Sumber daya finansial peneliti dapat menganalisis bahwa pendanaan untuk BUMDes sendiri dari Pemerintah Daerah membebaskan Pemerintah Desa untuk menganggarkan Dana Desa nya berapapun untuk BUMDes asalkan sesuai dengan perencanaan dan kesepakatan bersama, Dana yang saat ini ada pada BUMDes Desa Tanjungsari sebesar Rp.35.000.000 dengan jumlah dana yang ada, sangat kurang untukmengembangkan semua jenis usaha yang dijalankan maka Pemerintah Desa menyikapinya dengan mengambil skala prioritas dengan mengembangkan jenis usaha yang pertama adalah jenis usaha perdagangan yaiu dengan menyediakan bahan pokok kebutuhan seharihari dimana masyarakat dapat membayarnya dengan system kredit yang dilakukan dengan bantuan kader-kader posyandu untuk mensalurkan Sembilan bahan pokok tersebut.

Tabel 1

Jenis Usaha BUMDes

No Jenis Usaha BUMDes Desa Tanjungsari

1 Simpan Pinjam

2 Hasil Produksi Pertanian 
3 Penyaluran Sembilan bahan pokok

$4 \quad$ Penyewaan aat panggung

4 Pengelolaan pertambangan bahan galian

5 Pemeliharaan rutin jalan kabupaten

Peneliti melihat untuk ketersediaan dana pada dasarnya memang sudah ada tetapi berdasarkan sebagian pelaksana kebijakan tersebut dirasa kurang untuk mengembangkan semua jenis usaha karna dengan dana yang ada peneiti melihat belum dapat memberdayakan seluruh masyarakat. Pada dasarnya hal tersebut bukan menjadi alasan mengapa kebijakan tentang Pembentukan Badan Usaha Milik Desa ini tidak berjalan sesuai dengan semestinya.

\section{Karakteristik Agen Pelaksana}

Dalam Implementasi suatu kebijakan tidak akan terlepas dari yang namanya para pelaksana kebijakan, Para pelaksana kebijakan tersebut sangat mempengaruhi pada pencapaian suatu implementasi dalam artian baik atau tidaknya suatu implementasi kebijakan ditentukan oleh sejauhmana para pelaksana kebijakan tersebut bersungguh-sungguh dalam mengimplementasikan kebijakannya dan memiliki karakteristik yang sesuai dengan kebijakan tersebut. Karakteristik para pelaksana kebijakan (agen pelaksana) dapat menentukan keberhasilan suatu implementasi. Dilihat dari pernyataan diatas bahwa untuk mewujudkan BUMDes terbentuk di suatu desa bukanlah hal yang mudah karena terkadang masyarakat desa cenderung tradisional akan menghambat kearah pembangunan desa. Inisiatif pemerintah untuk melaksanakan BUMDes di seluruh desa akan sulit terwujud manakala pola fikir masyarakat desa masih belum berubah, seperti yang dikatakan oleh Direktur BUMDes Desa Tanjungsari bahwa Pola fikir masyarakat pemahaman masyarakat yang berfikir bahwa BUMDes itu adalah suatu pemberian secara cuma- cuma atau bisa dikatakan sebagai hibah dari pemerintah desa dan saya harus merubah paradigma 
masyarakat yang seperti itu. Selain pola fikir masyarakat yang masih belum mengerti akan pemahaman mengenai BUMDes juga pola fikir masyarakat lain bermunculan seperti yang disampaikan Kepala Desa Tanjungsari bahwa pola fikir masyarakat sekarang lebih kepada materil. Tentunya Mindset masyarakat ini harus diubah walaupun mindset bukan menjadi hambatan utama dalam menjalankan BUMDes namun jika masyarakat tidak ada kemauan bekerja untuk BUMDes demi kemajuan desa tentu akan sulit untuk mencapai tujuan yang akan di capai. Ditambah dengan kondisi pengurus yang beberapa dari mereka sibuk dengan pekerjaannya masingmasing hal ini diperkuat dengan pernyataan Kasi Pelayanan Desa Tanjungsari beliau mengatakan bahwa Hambatan untuk saat ini saya rasa ada pada pengurusnya karna dilihat belum dapat mengembangkan jenis usaha mungkin saya mengerti jika mereka sibuk dengan pekerjaan mereka satu sama lain tapi walaupun demikian tidak bisa begitu saja mengabaikan pekerjaan mereka di BUMDes Desa Tanjungsari.

Selanjutnya peneliti mewawancarai Seksi Bina Lembaga Ekonomi Desa DPMD Kab.Cianjur menyatakan bahwa untuk saat ini hambatan menurut saya bahwa Pemerintah Desa kurang mengarahkan ke pihak pengurus BUMDes untuk bagaimana BUMDes dapat dikelola dengan baik sekarang alokasi dana BUMDes dari dana desa menjadi prioritas jadi sekarang pemerintah desa seharusnya tinggal mengarahkan BUMDes dengan baik. walaupun besaran modalnya masih kecil itu tidak masalah karna pembentukan BUMDes kita juga harus rasional ketika unit usahanya hanya sekedar mengelola makanan kecil itu tidak apa apa karna jenis usaha yang dijalankannya harus sesuai dengan kondisi dan potensi yang ada di desa masing-masing.

Berdasarkan hasil wawancara dan observasi penelitian dilapangan peneliti melihat bahwa Karakteristik dari agen pelaksana berbeda-beda dari pengurus BUMDes yang cenderung sibuk dengan pekerjaannya sehingga mengabaikan tugasnya sebagai operasional BUMDes hal ini tentunya akan menghambat dari proses pencapaian tujuan yang ingin dicapai dan karakteristik dari agen pelaksana lainnya yaitu Pemerintah Desa dimana Pemerintah Desa kurang mengarahkan operasional BUMDes dalam 
pengembangan jenis usaha sehingga jenis usaha di Desa Tanjungsari belum berjalan dan karakteristik agen pelaksana yang terakhir adalah dari masyarakat dimana mindset pola fikir yang sifatnya masih tradisional dengan kurangnya pemahaman mengenai BUMDes.

\section{Sikap / kecenderungan (Disposition) Para Pelaksana}

Keberhasilan atau tidaknya kinerja implementasi kebijakan publik akan ditentukan dengan sikap penerimaan atau penolakan dari agen pelaksana maka dari itu sangat mungkin terjadi karna kebijakan yang dilaksanakan bukanlah hasil formulasi warga setempat yang mengenal betul persoalan dan permasalahan yang mereka rasakan. tetapi kebijakan yang akan implementor laksanakan adalah kebijakan "dari atas" (top dwon) yang sangat mungkin para pengambil keputusan tidak pernah mengetahui kebutuhan, keinginan, atau permasalahan yang warga ingin selesaikan.

Sikap penerimaan dalam pelaksanaan kebijakan BUMDes dengan ikut menjalankan serta mengelola BUMDes tersebut ditingkat desa dimulai dari penguatan kelembagaan dengan membentuk BUMDes. Penguatan komitmen pelaksana BUMDes dengan dibuatnya peraturan terkait BUMDes ditingkat daerah. Tanggapan dalam pelaksanaan BUMDes. Terkait hal itu dalam penguatan kelembagaan pemerintah desa memiliki perhatian untuk pelaksana operasional BUMDes seperti pernyataan dari Kepala Desa bahwa Pembentukan BUMDes di desa Tanjungsari ini berawal dari usulan Pemerintah Desa ke masyarakat dan diadakannya musyawarah desa yang sebelumnya kami sosialisasikan ke tiap RW untuk hadir dalam musyawarah desa yang membahas tentang pembentukan BUMDes juga kepengurusan BUMDes di dalam musyawarah desa juga kami membahas mengenai potensi desa karna dalam pembentukan BUMDes harus disesuaikan dengan kondisi potensi desa juga permodalannya nanti seperti apa sehingga hasil kesepakatan musyawarah desa menjadi pedoman bagi Pemerintah Desa dan BPD untuk menetapkan Peraturan Desa tentang 
Pedirian Badan Usaha Milik Desa.

Selanjutnya dalam penguatan komitmen dalam segi hukum ditingkat daerah seharusnya dibentuk 1 tahun setelah Permendagri diterbitkan, namun kenyataannya dilapangan bahwa pembentukan payung hukum tentang BUMDes di Kabupaten Cianjur dibuat pada tahun 2012 dan ditindaklanjuti pada tahun 2015 yaitu Peraturan Daerah Kabupaten Cianjur No. 4 Tahun 2015 Tentang Desa namun peraturan BUMDes tersebut dimuat tidak rinci karna akan diterangkan lebih lanjut pada Peraturan Bupati yang sampai saat ini belum keluar aturannya.

Di Kabupaten Cianjur Pemerintah Daerah dalam mengenalkan BUMDes ke desa-desa dilakukan dengan cara sosialisasi seperti yang dikatakan Seksi Bina Lembaga Ekonomi Desa DPMD Kabupaten Cianjur bahwa untuk sosialisasi kelapangan dengan satu kecamatan kita kumpulkan beberapa desa kita dorong untuk desa yang belum membentuk BUMDes dan berikutnya ada bimbingan teknis untuk BUMDes yang sudah berjalan jenis usahanya contohnya untuk jenis usaha produksi olahan pangan kita bantu untuk bagaimana pengemasan yang baik dan bagaimana untuk pemasaran melalui social media juga kami bantu mengarahkan dengan mendatangkan orang-orang yang ahli pada bidangnya.

Dari hasil wawancara dan observasi dilapangan bahwa peneliti melihat sikap yang ditemukan adalah sikap penerimaan dari berbagai pihak baik dari Pemerintah Desa yang memberikan perhatian untuk membentuk BUMDes sesuai dengan prosedur yang termuat dalam Permendesa No. 4 Tahun 2015, dan dari pihak Pemerintah Daerah yang membentuk peraturan terkait BUMDes yaitu Peraturan Daerah Kabupaten Cianjur No. 3 Tahun 2012 tentang Pedoman Tata Cara Pembentukan dan Pengelolaan Badan Usaha Milik Desa yang ditindaklanjuti dengan Peraturan Daerah Kabupaten Cianjur No.4 Tahun 2015 Tentang Desa.

Pemerintah Desa dalam menyikapi BUMDes diterima dengan sikap penerimaan yaitu dengan dibuatnya BUMDes yang sesuai dengan prosedur tata cara pembentukannya yang termuat dalam Permendesa No. 4 Tahun 2015 namun peneliti juga melihat bahwa ada ketidaktegasan dari 
Pemerintah Desa dalam menghadapi masalah pada operasional BUMDes, sehingga dengan demikian untuk memaksimalkan proses implementasi kebijakan tersebut diperlukan suatu ketegasan yang nyata terhadap setiap permasalahan yang ada yaitu jika pengurus dari BUMDes yang kurang bertanggung jawab terhadap pekerjaaannya terhadap BUMDes karna lebih mementingkan pekerjaan yang diluar BUMDes sehingga mengabaikan pekerjaan dia sebagai pengurus BUMDes yang harus mengelola BUMDes dengan baik.

BUMDes harus dikelola dengan Profesional sehingga diperlukan orangorang yang bertanggungjawab dalam mengelolaannya jika dalam mengelolaannya tidak diikuti dengan orang-orang yang berkompeten maka BUMDes tidak akan menghasilkan keuntungan apapun, Dalam Peraturan Desa Tanjungsari No. 3 tahun 2017 tentang Pembentukan Badan Usaha Milik Desa pada pasal 21 menyatakan bahwa Pegawai BUMDes wajib mendahulukan kepentingan BUMDes diatas kepentingan lainnya, Apabila ada pegawai yang melanggar maka pegawai BUMDes maka sanksinya adalah pegawai tersebut harus diberhentikan sementara.

Tabel 2

Pelaksana Operasional BUMDes Desa Tanjungsari

\begin{tabular}{|c|c|c|c|c|}
\hline No & Nama & Alamat & Jabatan & Pendidikan \\
\hline 1 & Maftuhudin A & $\begin{array}{l}\text { Kp. Sodong, RT } 05 \\
/ 01\end{array}$ & Direktur & - \\
\hline 2 & Ikbal Maulana & Kp. Tojong, 01/05 & Sekertaris & SMA \\
\hline 3 & Irah Sutirah & Kp. Tojong, 01/05 & Bendahara & SMA \\
\hline 4 & Mansyur & Kp. Sodong, 01/01 & $\begin{array}{l}\text { Unit } \\
\text { ha Usa } \\
\text { penyewaa } \\
\text { n }\end{array}$ & $\mathrm{SD}$ \\
\hline 5 & Neng Ila siti & $\begin{array}{l}\text { Kp. Karanganyar } \\
04 / 01\end{array}$ & $\begin{array}{l}\text { Unit } \\
\text { ha Usa } \\
\text { Perdagang }\end{array}$ & $\mathrm{S} 1$ \\
\hline
\end{tabular}




\begin{tabular}{|c|c|c|c|c|}
\hline & & & an & \\
\hline 6 & Aceng Kodir & $\begin{array}{l}\text { Kp. Sukahurip, } \\
05 / 05\end{array}$ & $\begin{array}{l}\text { Unit } \\
\text { ha Usa } \\
\text { Perantara }\end{array}$ & - \\
\hline 7 & $\begin{array}{l}\text { Weni } \\
\text { i S.Pd Rosdian }\end{array}$ & Kp. Tojong, 01/05 & $\begin{array}{l}\text { Unit } \\
\text { ha Usa } \\
\text { Keuangan }\end{array}$ & $\mathrm{S} 1$ \\
\hline 8 & Ujang Utom & $\begin{array}{l}\text { Kp. Mekar Asih, } \\
04 / 03\end{array}$ & $\begin{array}{l}\text { Unit } \\
\text { ha } \\
\text { Bersama }\end{array}$ & SMP \\
\hline
\end{tabular}

Sumber : Desa Tanjungsari, 2017

Berdasarkan tabel diatas ditemukan beberapa pelaksana operasional yang tingkat pendidikannya rendah yaitu Bapak Mansyur dengan tingkat pendidikanya SD dan Bapak Ujang Utom dengan tingkat pendidikannya SMP sedangkan dalam Peraturan Desa Tanjungsari No. 3 Tahun 2017 Tentang Pembentukan Badan Usaha Milik Desa pada pasal 20 menyatakan bahwa :

(1) untuk dapat diangkat menjadi pegawai BUMDes harus memenuhi persyaratan:
a. Warga Negara Republik Indonesia
b. Penduduk Desa Tanjungsari Kecamatan Sukaluyu yang dibuktikan dengan Kartu Tanda Penduduk
c. sekurang kurangnya berijazah Pendidikan SLTA dan diutamakan Kejuruan atau Diploma III
d. Berkelakukan baik
e. mempunyai Pendidikan, Kecakapan dan keahlian yang dipeerlukan
f. dinyatakan sehat oleh dokter negeri
g. usia paling rendah 23 tahun dan paling tinggi 35 Tahun
h. lulus seleksi

Berdasarkan aturan tersebut bahwa dinyatakan untuk menjadi pegawai BUMDes sekurang-kurangnya berijazah Pendidikan SLTA dan diutamakan kejuruan atau Diploma III, namun kenyataannya dilapangan bahwa ada beberapa pengurus yang tingkat Pendidikannya rendah, hal 
tersebut membuktikan bahwa Pemerintah Desa tidak mempatuhi aturan yang ada, peneliti dapat menganalisis bahwa konsistensi dari implementor melaksanakan kebijakan dengan peraturan yang telah ditentukan sebelumnya pada Peraturan Desa Tanjungsari No. 3 Tahun 2017 Tentang Pembentukan Badan Usaha Milik Desa belum konsisten dilaksanakan karna ada masih ada beberapa yang tidak sesuai dengan aturan yang ada sehingga mengakibatkan pengurus BUMDes bersikap tidak patuh. Padahal konsistensi merupakan hal yang penting dalam penyelenggaraan pelaksanaan Badan Usaha Milik Desa.

\section{Komunikasi antar Organisasi dan Aktivitas Pelaksana}

Dalam proses implementasi suatu kebijakan komunikasi merupakan hal yang sangat penting. Karena dengan baiknya komunikasi antar organisasi ataupun antar individu pelaksana kebijakan maka akan terciptalah suatu kordinasi yang baik. Seperti dalam proses Implementasi Kebijakan Pemerintah Desa tentang Pembentukan Badan Usaha Milik Desa komunikasi yang terjadi pada Pemerintah Daerah dengan Pemerintah Desa tidak rutin dilakukan seperti yang disampaikan oleh Kepala Desa Tanjungsari bahwa komunikasi yang dilakukan mengenai BUMDes awalnya lewat sosialisasi BUMDes Pada tahun 2015 dari Pemerintah Daerah mengenai Peraturan Daerah No. 4 tahun 2015 Tentang Desa yang mana didalamnya membahas mengenai badan usaha miik desa namun dalam sosialisasi yang diberikan pemerintah daerah itu tidak membicarakan secara teknis secara lebih dalam.

Pernyataan tersebut juga diperkuat oleh Direktur BUMDes Desa Tanjungsari menyatakan bahwa sampai saat ini dari Pemerintah Daerah pun belum memberikan arahan khusus langsung kepada BUMDes dalam pengelolaannya seperti memberikan pelatihan contohnya itu belum ada tapi untuk pelatihan sendiri saya dapatkan dari luar seperti yayasan-yayasan yang mengadakan pelatihan tentang usaha perekonomian namun untuk ke teknis pengelolaan BUMDes nya itu saya belum pernah karna dari pemerintah daerah maupun pemerintah desa pun belum mengadakan program khusus untuk pengelolaan BUMDes baik itu program pelatihan 
atau mengembangan jenis usaha dan juga untuk rapat antar pengurus dilakukan satu bulan sekali. Namun untuk kordinasi Pemerintah Desa dengan Karangtaruna sendiri terjalin dengan baik seperti yang dikatakan oleh Pengurus Karangtaruna Desa Tanjungsari bahwa Sejauh ini kami sering melakukan pertemuan dengan pemerintah desa terkait dengan pengelolaan badan usaha milik desa yang ada di desa tanjungsari ini,

Selanjutnya peneliti melakukan wawancara dengan Kasi Pelayanan Desa Tanjungsari beliau menyatakan bahwa komunikasi yang ada saat ini dengan dinas_dinas terkait seperti dinas pertanian sebetulnya ada mengenai bibit atau membahas bantuan penunjang pertanian lainnya namun untuk membahas hasil pertanian yang nantinya akan menjadi jenis usaha Badan Usaha Milik Desa ini belum ada komunikasi kearah situ namun nanti ketika jenis usaha nya hasil pertanian akan di jalankan pastinya kami akan berkomunikasi lebih lanjut dengan pihak pertanian lagi komunikasi dengan masyarakat umum belum ada sosialisasi namun untuk masyarakat khusus seperti para kader posyandu atau ketua RW lainnya sudah ada sosialisasi dan mereka mendukung akan lahirnya BUMDes.

Dari hasil wawancara dan observasi yang peneliti lakukan maka peneliti menganalisis bahwa komunikasi antara Pemerintah Daerah dan Pemerintah Desa tidak rutin dilaksanakan dilihat dari Pemerintah Daerah dan Pemerintah Desa belum mengadakan program khusus untuk BUMDes yang baru berkembang, dapat dilihat dari pernyataan diatas bahwa Pemerintah Daerah hanya memberikan pelatihan untuk BUMDes yang sudah berkembang seperti memberikan cara pengemasan yang baik untuk BUMDes yang sudah berkembang dengan jenis usaha makanan di desa lain dan untuk di desa Tanjungsari sendiri belum ada bimbingan teknis tersebut sehingga untuk pelatihan ekonomi sendiri mereka dapatkan dari luar itupun tidak ada kaitannya dengan BUMDes seharusnya baik itu Pemerintah Daerah atau Pemerintah Desa memberikan pelatihan khusus untuk pengurus agar dalam mengembangkan jenis usahanya segera berjalan. 


\section{Lingkungan Ekonomi, Sosial dan Politik.}

Hal terakhir yang harus diperhatikan dalam mengimplementasikan suatu kebijakan adalah suatu dimensi yang menggambarkan mengenai kondisi lingkungan sekitar yang dapat mempengaruhi pada proses implementasi kebijakan, yang ditawarkan oleh Van Metter dan Van Horn adalah sejauh mana lingkungan eksternal turut mendorong keberhasilan kebijakan publik yang telah ditetapkan lingkungan eksternal sendiri terdiri dari lingkungan sosial, ekonomi dan politik.

Berdasarkan hasil pengamatan peneliti lakukan dari pekerjaan penduduk Desa Tanjungsari pada tahun 2017 dapat dilihat dalam tabel berikut:

\section{Tabel 3}

Penduduk Berdasarkan Status Pekerjaan

\begin{tabular}{|c|c|c|}
\hline No & Jenis Pekerjaan & Jumlah \\
\hline 1 & Petani & 3120 orang \\
\hline 2 & Buruh Tani & 1984 orang \\
\hline 3 & Buruh Swasta & 175 orang \\
\hline 4 & Pegawai Negeri Sipil & 120 orang \\
\hline 5 & Pedagang & 621 orang \\
\hline 6 & Montir & 10 orang \\
\hline 7 & Peternak & 10 orang \\
\hline 8 & Tukang & 180 orang \\
\hline 9 & Lain-lain & 80 orang \\
\hline
\end{tabular}

Sumber : RPJMDesa Tanjungsari

Dari Tabel di atas diketahui bahwa di Desa Tanjungsari mayoritas penduduk bekerja sebagai petani tentunya hal ini dapat dimanfaatkan Pemerintah Desa Tanjungsari dengan menetapkan jenis usaha hasil pertanian oleh BUMDes, dengan ini Desa Tanjungsari akan memiliki dukungan dari para petani.

Dari hasil wawancara dan observasi yang peneliti lakukan maka peneliti menganalisis bahwa, lingkungan ekonomi dalam implementasi 
BUMDes memang perekonomian masyarakat desanya dapat dikatakan menengah kebawah, bahwa masih banyak masyarakat yang belum mempunyai pekerjaan namun jika cermati dengan kondisi ekonomi yang seperti itu maka pembentukan BUMDes di Desa Tanjungsari akan mendapatkan dukungan dari masyarakat dengan harapan masyarakat akan di berdayakan dan masyarakat akan dibantu dengan jenis usaha yang nantinya akan dijalankan. Selanjutnya dari lingkungan politik peneliti dapat menganalisis bahwa kondisi lingkungan dalam konteks politik yang ada di Desa Tanjungsari ini masalah yang dihadapi yaitu adanya penolakan dari beberapa masyarakat yang dahulunya tidak mendukung kepala desa pada saat pemilihan namun masalah tersebut masih dalam tahap aman sehingga tidak mempengaruhi pada proses implementasi kebijakan pemerintah desa tentang pembentukan badan usaha milik desa di Desa Tanjungsari.

Lingkungan sosial masyarakat Desa Tanjungsari juga mendukung jalannya kebijakan BUMDes ini, dengan mayoritas petani, pedagang atau kelompok usaha yang kekurangan modal tentunya masyarakat tersebut akan membutuhkan bantuan dari pemerintah desa salah satunya melalui BUMDes untuk bisa memperbaiki taraf kehidupannya namun dalam mengembangan jenis usaha pertanian ini harus lebih berhati-hati jangan sampai nantinya pembelaku bisnis atau tengkulak di Desa Tanjungsari yang sebelumnya pengambilan hasil panen oleh mereka merasa tersaingi sehingga jika nantinya jenis usaha ini berkembang tidak ada pihak yang dirugikan baik itu para petani atau pemberlaku bisnis di Desa Tanjungsari.

\section{KESIMPULAN}

\section{Ukuran dan Tujuan Kebijakan}

Tujuan kebijakan BUMDes Desa Tanjungsari secara umum yaitu untuk meningkatkan kualitas kehidupan masyarakat secara akumulatif, berdasarkan tujuan kebijakan tersebut bahwa BUMDes Desa Tanjungsari belum mampu memberdayakan seluruh masyarakat desa karna masih terhambat akan SDM juga pendanaan. 
Ukuran suatu kebijakan dapat dilihat dari berhasil atau tidaknya diukur dari banyaknya desa yang memiliki BUMDes, di Kabupaten Cianjur sendiri dari 354 Desa yang ada hanya 123 BUMDes di Kabupaten Cianjur dengan demikian kurang dari 50\% Desa yang membentuk BUMDes.

\section{Sumberdaya}

Pemerintah Desa belum menerapkan seleksi yang ketat dalam memilih pengurus BUMDes dikarenakan sedikit dari masyarakat yang berminat menjadi pengurus BUMDes, dan pengurus BUMDes yang ada pada saat ini cenderung sibuk dengan pekerjaannya masing-masing sehingga dalam mengimplementasikan kebijakan pemerintah desa tentang pembentukan badan usaha milik desa ini tidak diikuti dengan pengembangan jenis usaha dan beberapa dari pengurus dengan tingkat Pendidikan yang rendah sehingga mempengaruhi kinerja yang rendah juga. Terkait ketersediaan finansial pada Implementasi Kebijakan Pemerintah Desa Tentang Pembentukan Badan Usaha Milik Desa di Desa Tanjungsari saat ini dana yang ada belum mencukupi untuk mengembangkan semua jenis usaha maka untuk mensiasatinya dengan memilih jenis usaha yang akan di prioritaskan yaitu jenis usaha perdagangan berdasarkan jenis usaha yang diprioritaskan tersebut tidak sesuai dengan kebutuhan masyarakat desa.

\section{Karakteristik Agen Pelaksana}

Karakteristik dari agen pelaksana BUMdes berbeda-beda, pertama dari pengurus BUMDes yang cenderung sibuk dengan pekerjaannya sehingga mengabaikan tugasnya sebagai operasional BUMDes hal ini tentunya akan menghambat dari proses pencapaian tujuan yang ingin dicapai. Karakteristik yang selanjutnya dari agen pelaksana lainnya yaitu Pemerintah Desa dimana Pemerintah Desa kurang mengarahkan operasional BUMDes dalam pengembangan jenis usaha sehingga jenis usaha di Desa Tanjungsari belum berjalan dan Karakteristik agen pelaksana yang terakhir adalah dari masyarakat dimana mindset pola fikir yang sifatnya masih tradisional dengan kurangnya pemahaman mengenai BUMDesa. 


\section{Sikap / kecenderungan (Disposition) Para Pelaksana}

Sikap yang ditemukan adalah sikap penerimaan dari berbagai pihak baik dari Pemerintah Desa maupun dari Pemerintah Daerah. Pemerintah Desa yang memberikan perhatian untuk membentuk BUMDes walaupun terdapat ketidaktegasan pemerintah desa dan kepatuhan agen pelaksana terhadap aturan yang ada.

\section{Komunikasi antar Organisasi dan Aktivitas Pelaksana}

Komunikasi antara Pemerintah Daerah dan Pemerintah Desa tidak bertindak sebagai fasilitator terhadap upaya BUMDes dalam mencapai tujuannya dan juga tidak bertindak sebagai pemberi informasi kepada BUMDes untuk meningkatkan kinerjanya dilihat dari belum mengadakan program khusus untuk BUMDes yang baru berkembang. Untuk Komunikasi dengan Karangtaruna dapat dikatakan komunikasinya berjalan dengan baik dilihat dari Pemerintah Desa sudah memberdayakan orangorang yang ada di karangtaruna untuk menjadi pengurus BUMDes namun untuk komunikasi dengan masyarakat berbanding terbalik dimana dalam mensosialisasikan BUMDes belum seluruhnya menyentuh masyarakat Desa Tanjungsari dan Komunikasi antar organisasi sendiri perlu ditingkatkan lagi karna jenis usaha yang akan dikembangkan oleh BUMDes Desa Tanjungsari akan berjalan dengan baik apabila komunikasi antar dinasdinas terkait berjalan dengan baik pula.

\section{Lingkungan Ekonomi, Sosial, Politik}

Kesimpulan kondisi eksternal yang terdiri dari lingkungan ekonomi, sosial dan politik dalam implementasi Kebijakan Pemerintah Desa Tentang Pembentukan Badan Usaha Milik Desa berjalan dengan Kondusif.

\section{DAFTAR PUSTAKA}

Agustino, Leo. 2016. Dasar-dasar Kebijakan Publik (edisi revisi). Bandung : Alfabeta

Dunn, William N. 2002. Analisis Kebijakan Publik (Penyadur : DR. Muhadjir Darwin). Yogyakarta : Hanidita Graha Widya 
Sugiyono. 2013. Metodelogi Penelitian Administrasi. Bandung : Alfabeta

Solkhan. Moch. 2014. Penyelenggaraan Pemerintahan Desa Berbasis Partisipasi Masyarakat. Malang : Setara Prss

Wahab Abdul, Solichim. 2002. Analisis Kebijakan dari Formulasi ke Implementasi Kebijakan Negara. Jakarta : Bumi Aksara

Winarno, Budi. 2007. Kebijakan Publik Teori dan Proses. Jakarta : Medpress Winarno, Budi. 2012. Teori dan proses kebijakan publik. Jakarta : Medpress

Republik Indonesia Undang-Undang Nomor 23 Tahun 2014 tentang Pemerintahan Daerah

Republik Indonesia Undang-Undang Nomor 6 Tahun 2014 tentang Desa Peraturan Menteri Dalam Negeri Nomor 39 Tahun 2010 Tentang Badan Usaha Milik Desa

Peraturan Menteri Desa Nomor 4 Tahun 2015 tentang Pendirian, Pengurusan, Pengelolaan dan Pembubaran Badan Usaha Milik Desa

Peraturan Daerah Kabupaten Cianjur Nomor 3 tahun 2012 tentang Pedoman Tata Cara Pembentukan dan Pengelolaan Badan Usaha Milik Desa

Peraturan Daerah Kabupaten Cianjur Nomor 04 Tahun 2015 tentang Desa

Peraturan Desa Tanjungsari Nomor 3 tahun 2017 tentang Pembentukan Badan

Usaha Milik Desa. 